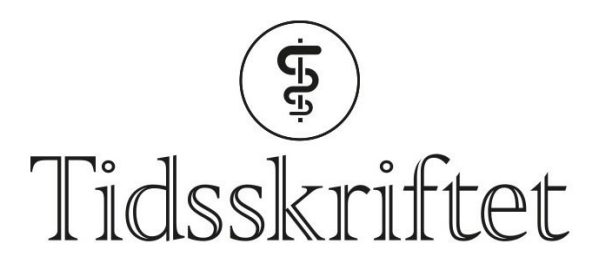

DEN NORSKE LEGEFORENING

\title{
Ablasjon eller legemidler ved atrieflimmer?
}

FRA ANDRE TIDSSKRIFTER

PETTER MORTEN PETTERSEN

Tidsskriftet

Risikoen for død og kardiovaskulære hendelser synes å være omtrent den samme etter kateterablasjon som ved medikamentell behandling av atrieflimmer. Dette viser en ny studie.

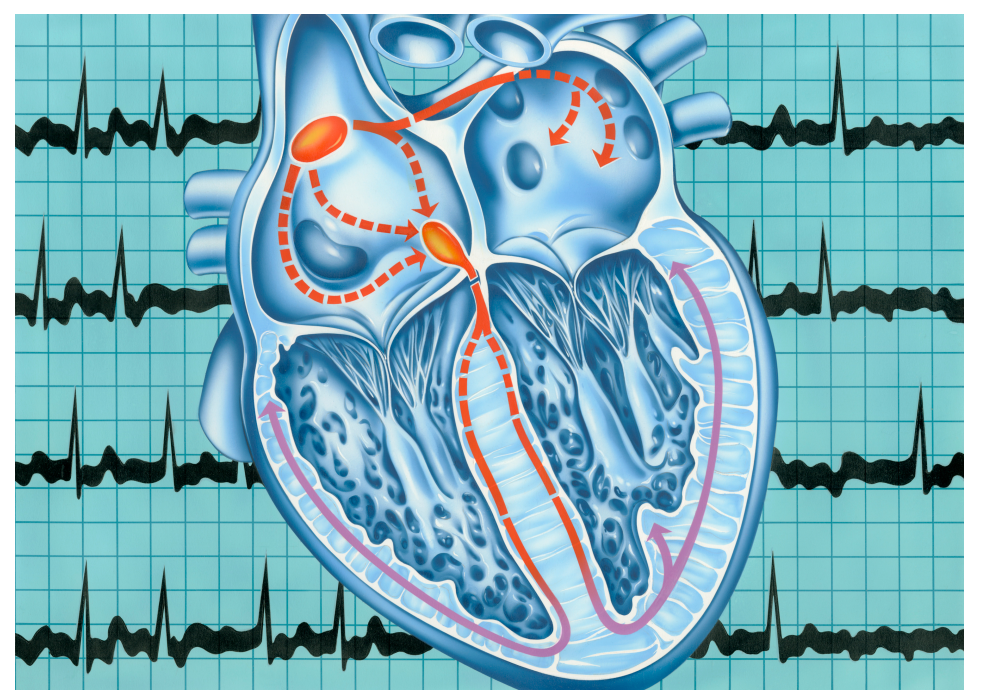

Illustrasjon: Science photo library/ NTB Scanpix

Atrieflimmer kan behandles med kateterablasjon, dvs. å lage en minimal vevsskade i det området som mistenkes å starte eller opprettholde de elektriske stimuli som gir atrieflimmer. Dermed gjenvinnes regelmessig hjerterytme, men langtidseffekten på dødelighet og forekomst av hjerneslag, blødninger og hjertestans er ikke avklart.

I en multisenterstudie ble rundt 2200 pasienter med atrieflimmer randomisert til kateterablasjon eller behandling med rytme- og/eller frekvenskontrollerende legemidler etter gjeldende retningslinjer (1). Etter en median oppfølgingstid på fire år inntraff død, funksjonsnedsettende hjerneslag, alvorlige blødninger og hjertestans hos hhv. 8,o \% og 9,2 \% av pasientene $(\mathrm{p}=0,30)$. Det var færre residiv av atrieflimmer i ablasjonsgruppen enn blant dem som fikk legemidler, hhv. $50 \%$ og $70 \%(\mathrm{p}<0,001)$. Rundt 300 pasienter som ble randomisert til legemidler, fikk ablasjonsbehandling i løpet av oppfølgingstiden.

- Pasienter med samtidig alvorlig hjertesvikt og atrieflimmer kan se ut til å ha bedre overlevelse ved ablasjon, sier Dan Atar, som er professor ved Hjertemedisinsk avdeling, Oslo 
universitetssykehus, Ullevål. Denne studien hadde som hensikt å se om «vanlige» pasienter med atrieflimmer fikk $\emptyset \mathrm{kt}$ overlevelse av ablasjon, men studien mislyktes med å vise dette, blant annet på grunn av den store overkrysningsraten, sier han.

- Det er vist i mange studier at kateterablasjon ved atrieflimmer er bedre for å holde pasienter i sinusrytme. Denne studien bekrefter at ablasjon er et foretrukket behandlingsvalg hos symptomatiske pasienter som har prøvd medikamentell behandling, sier Atar.

- Etablert praksis ved symptomatisk atrieflimmer i Norge er først å forsøke rytmestabiliserende legemidler. Dersom denne behandlingen ikke virker og pasienten ikke er skrøpelig, kan ablasjon forsøkes, sier Atar.

LITTERATUR:

1. Packer DL, Mark DB, Robb RA et al. Effect of catheter ablation vs antiarrythmic drug rherapy on mortality, stroke, bleeding, and cardiac arrest among patients with atrial fibrillation. The CABANA Randomized Clinical Trial. JAMA 2019;321: 1261. [PubMed][CrossRef]

Publisert: 5. juni 2019. Tidsskr Nor Legeforen. DOI:10.4045/tidsskr.19.0282

(C) Tidsskrift for Den norske legeforening 2020. Lastet ned fra tidsskriftet.no 